\title{
Catalytic and kinetic properties of purified Eichhornia crassipes leaf peroxidase
}

\section{Rotimi Olusanya Arise*, Bolaji Olajide Osundahunsi, Samuel Tobi Farohunbi, Abeeb Abiodun Yekeen}

Department of Biochemistry, Faculty of Life Sciences, University of Ilorin, Ilorin, Nigeria

${ }^{\star}$ Corresponding author, E-mail: ariserotimi@gmail.com

\begin{abstract}
Peroxidase from Eichhornia crassipes leaf was purified 23.58 fold with $18.58 \%$ yield by means of $\left(\mathrm{NH}_{4}\right)_{2} \mathrm{SO}_{4}$ precipitation, ion exchange and Sephadex G-75 gel filtration chromatography. Optimum temperature and substrate-dependent $\mathrm{pH}$ optimum for enzyme activity were $40{ }^{\circ} \mathrm{C}$ and $\mathrm{pH}$ 4.0, 9.0 and 6.0 for 2,2'-azino-bis-(3-ethylbenzthiazolin)-6-sulfonate (ABTS), guaiacol and pyrogallol, respectively. The enzyme had high $\mathrm{pH}$ stability and moderate thermal stability at temperatures up to $60{ }^{\circ} \mathrm{C}$; the activation energy of inactivation of the enzyme was $\sim 122.29 \mathrm{~kJ} \mathrm{~mol}^{-1}$. Temperature-denaturing and spontaneous recovery were shown to be time-dependent while $\mathrm{Ca}^{2+}$ enhanced recovery of the denatured enzyme was in a time-dependent manner. The enzyme showed preferential affinity for ABTS over guaiacol and pyrogallol with $\mathrm{K}_{\mathrm{M}}$ values of $31.11,21.91$ and $6.45 \mathrm{mM}$ respectively. It was reversibly inhibited by $\mathrm{Pb}^{2+}, \mathrm{Hg}^{2+}$ and $\mathrm{EDTA}^{2}$ while urea only caused loss of $\sim 30.40 \%$ activity after $60 \mathrm{~min}$ of incubation. E. crassipes leaf peroxidase has potential use for broad range of applications.
\end{abstract}

Key words: Eichhornia crassipes, peroxidase, $\mathrm{pH}$ and thermal stability, optimum temperature. Abbreviations: ABTS, 2,2'-azino-bis-(3-ethylbenzothiazoline)-6-sulfonate.

\section{Introduction}

Peroxidases are common in nature. They catalyze the oxidation of several important substrates and play important roles in various physiological processes in plants (Passardi et al. 2005; Hamid, Khalil-ur-Rehman 2009). They are heme-containing proteins and are involved in the oxidation of broad range of substrates using hydrogen peroxide as the oxidant (Adam et al. 1999; Galati, O'Brien 2004). Peroxidases have been used in biotechnology, biomedicine, pharmacy and agriculture (Veitch, Smith 2001). Presently, horseradish peroxidase is the major commercial form of the enzyme. However, studies are still ongoing to identify peroxidases from other sources with properties suitable for biotechnological, biomedical and other industrial applications (Regalado et al. 2004). Some peroxidases from these sources have shown potential for applications as biocatalysts and bioelectrocatalysts (Adam et al. 1999; Torres et al. 2003; Carlos et al. 2005).

Several peroxidases have been identified as possessing important properties such as thermal stability, $\mathrm{pH}$ stability, and resistance to chemical denaturing, which make them suitable for use as biocatalysts. Purified peroxidases have been obtained from diverse plant sources (Deepa, Arumughan 2002), such as spring cabbage, soy bean and rice leaves (Ito et al. 1991), tea (Kvaratskhelia et al. 1997), okra (Yemenicioglu et al. 1998), Ipomoea palmetto (Srinivas et al. 1999) and Copaifera longsdorffi (Maciel et al. 2007). However, less attention has been directed toward sources that are naturally widely available and regarded as unwanted in the environment. Eichhornia crassipes, also widely known as water hyacinth, is an aquatic plant that is considered to be one of the world's persistent weeds. It is characterized by an aggressive growth pattern. Its abundance and persistence in many water bodies throughout the world favour its consideration as a pontential source of novel peroxidases (Fabricio et al. 2004). In this study, peroxidase was isolated from E. crassipes leaves and characterized for its kinetic properties and catalytic conditions. Improvement of the purification process could contribute to making it prospective for industrial applications.

\section{Materials and methods}

\section{Materials}

Fresh and healthy leaves of Eichhornia crassipes were collected from Asa Dam River in Ilorin, Kwara state, Nigeria. Ammonium sulphate and Sephadex G-75 were obtained from BDH Chemicals, England, guaiacol from Santa Cruz Biotech, USA. 2,2'-azino-bis-(3-ethylbenzthiazolin)-6sulfonate (ABTS) and pyrogallol from Sigma-Aldrich, USA. All chemicals used in this study were of analytical grade and used without further purification. 


\section{Ammonium sulphate precipitation and dialysis}

E. crassipes leaves were transported to the laboratory in a flask containing ice packs. Homogenate of E. crassipes leaves was obtained by homogenizing leaves $(50 \mathrm{~g})$ in 250 $\mathrm{mL}$ cold $100 \mathrm{mM}$ Tris- $\mathrm{HCl}$ buffer, $\mathrm{pH}$ 7.5, in a blender, and filtering through a multilayer of cheese cloth. Homogenate was then centrifuged at $10000 \mathrm{~g}$ for $15 \mathrm{~min}$ at $4{ }^{\circ} \mathrm{C}$. The supernatant was then precipitated with $\left(\mathrm{NH}_{4}\right)_{2} \mathrm{SO}_{4}$ at 4 ${ }^{\circ} \mathrm{C}$ overnight for complete precipitation. Saturations of $\left(\mathrm{NH}_{4}\right)_{2} \mathrm{SO}_{4}$ between 0 and $50 \%$ as well as 50 and $90 \%$ were analyzed for peroxidase activity. Precipitate was collected by centrifuging the solution at $10000 \mathrm{~g}$ for $15 \mathrm{~min}$ at $4{ }^{\circ} \mathrm{C}$ in a cold centrifuge.

The fraction obtained by 50 to $90 \%$ saturation had higher peroxidase activity and was selected for further purification. The precipitate was dissolved in the isolating buffer and dialyzed against $100 \mathrm{mM}$ Tris- $\mathrm{HCl}$ buffer, $\mathrm{pH} 7.5$ over a period of $24 \mathrm{~h}$ with three changes of buffer at regular intervals. Protein concentration was estimated using bovine serum albumin as a standard protein as described by Lowry et al. (1951). The specific enzyme activity was calculated and the purification yield was determined (Rudrappa et al. 2007).

\section{lon exchange chromatography}

The dialysed fraction was loaded on a DEAE cellulose column $(1 \times 30 \mathrm{~cm})$ that was pre-equilibrated in $100 \mathrm{mM}$ Tris- $\mathrm{HCl}$ buffer, $\mathrm{pH}$ 7.5. Bound enzyme was eluted stepwise with a 0 to $150 \mathrm{mM} \mathrm{NaCl}$ gradient in $100 \mathrm{mM}$ Tris- $\mathrm{HCl}$ buffer, $\mathrm{pH}$ 7.5. The fractions were collected in volume $5 \mathrm{~mL}$ each. Each fraction was then assayed to determine enzyme activity using guaiacol as reducing substrate and the total protein concentration estimated. Fractions with high activity were pooled together and used in the next purification step.

\section{Gel filtration chromatography}

Fractions with high specific activity were subjected to molecular weight filtration using Sephadex G-75 in a $1 \times$ $40 \mathrm{~cm}$ column that was pre-equilibrated with $100 \mathrm{mM}$ Tris$\mathrm{HCl}$ buffer, $\mathrm{pH}$ 7.5. The column was washed with eluting buffer (same as the equilibrating buffer) and fractions were collected in volume $5 \mathrm{~mL}$ each per fraction. The fractions were then assayed for their enzyme activity and the total protein estimated. Fractions with the highest specific activity were identified and used for characterization.

\section{Assay of peroxidase activity}

Standard peroxidase assay was performed at room temperature. Three assay methods were used to determine peroxidase activity with different reducing substrates. Peroxidase activity with guaiacol as a reducing substrate was carried out as described by $\mathrm{Hu}$ et al. (2012) with modifications. Briefly, $0.1 \mathrm{~mL}$ of enzyme source was added to $0.1 \mathrm{M}$ phosphate buffer, $\mathrm{pH}$ 7.0. Then $0.1 \mathrm{mM}$ guaiacol was added. The reaction was started with $150 \mathrm{mM} \mathrm{H}_{2} \mathrm{O}_{2}$. The total volume of the reaction mixture was $3.0 \mathrm{~mL}$. Change in absorbance at $470 \mathrm{~nm}$ was estimated using a spectrophotometer (visible spectrophotometer 721D, Axiom Medical Ltd, UK) over a period of $3 \mathrm{~min}$ with $1 \mathrm{~min}$ interval.

The activity of peroxidase using ABTS as a reducing substrate was determined as described by Gray and Montgomery (2003) with slight modifications. The reaction mixture contained $1.67 \mathrm{mM}$ ABTS, $0.1 \mu \mathrm{L}$ enzyme, $150 \mathrm{mM}$ $\mathrm{H}_{2} \mathrm{O}_{2}$, and $0.1 \mathrm{mM}$ sodium acetate buffer, $\mathrm{pH}$ 4.0. Change in absorbance was measured at $415 \mathrm{~nm}$ over a period of $3 \mathrm{~min}$ at interval of $1 \mathrm{~min}$. Assay for peroxidase using pyrogallol as a reducing substrate was carried out as described in the Sigma-Aldrich procedure manual. The reaction mixture contained $0.32 \mathrm{~mL} 5 \%$ pyrogallol, $0.16 \mathrm{~mL} 147 \mathrm{mM} \mathrm{H}_{2} \mathrm{O}_{2}$, $0.32 \mathrm{~mL}$ phosphate buffer $\mathrm{pH} 6.5,2.1 \mathrm{~mL} \mathrm{H}_{2} \mathrm{O}$ and $0.1 \mathrm{~mL}$ enzyme. Change in absorbance was monitored at $590 \mathrm{~nm}$ using a spectrophotometer (visible spectrophotometer 721D, Axiom Medical Ltd, UK). All assays where read over a period of $3 \mathrm{~min}$.

The following molar extinction coefficients were used in calculating peroxidase activity with different substrates; ABTS $\left(36.0 \mathrm{mM} \mathrm{cm}^{-1}\right)$, guaiacol $\left(26.6 \mathrm{mM} \mathrm{cm}^{-1}\right)$, pyrogallol $\left(2.6 \mathrm{mM} \mathrm{cm}^{-1}\right)$. In all assays, the change in absorbance represented colour development as a result of the product formed and expressed as $\mu \mathrm{mol}$ of product formed per minute by E. crassipes leaf peroxidase. Except when otherwise stated, the reducing substrate used in this study was guaiacol.

\section{Determination of $\mathrm{pH}$ optimum and stability of peroxidase}

Optimum $\mathrm{pH}$ of E. crassipes leaf peroxidase was determined for three reducing substrates, ABTS, guaiacol and pyrogallol. Optimum $\mathrm{pH}$ for ABTS was determined using Mcllvaine buffer prepared as described by Dawson et al. (1986). Peroxidase activity was tested over a pH range of 2.0 to 8.0. For guaiacol, peroxidase activity was determined using a buffer range as described by Khatun et al. (2012). Optimum $\mathrm{pH}$ of pyrogallol was determined using buffers as used in assay for peroxidase activity with guaiacol. $\mathrm{pH}$ stability of the enzyme was determined using guaiacol as a substrate and the same buffer range as previously described. The enzyme was incubated with specific buffers of known $\mathrm{pH}$ range for a period of $24 \mathrm{~h}$ at $4{ }^{\circ} \mathrm{C}$, and peroxidase activity was determined after this time.

\section{Determination of optimum temperature and thermal stability of peroxidase}

The optimum temperature of E. crassipes leaf peroxidase was determined by assaying peroxidase activity at temperatures between 20 and $80^{\circ} \mathrm{C}$ at $10{ }^{\circ} \mathrm{C}$ intervals. Heat of inactivation was determined by measuring enzyme activity $\left(\mathrm{A}_{\mathrm{o}}\right)$ at 40 , 50, 60 and $70{ }^{\circ} \mathrm{C}$. Briefly, an enzyme sample was heated at a specific temperature over a period of $60 \mathrm{~min}$. Aliquot 

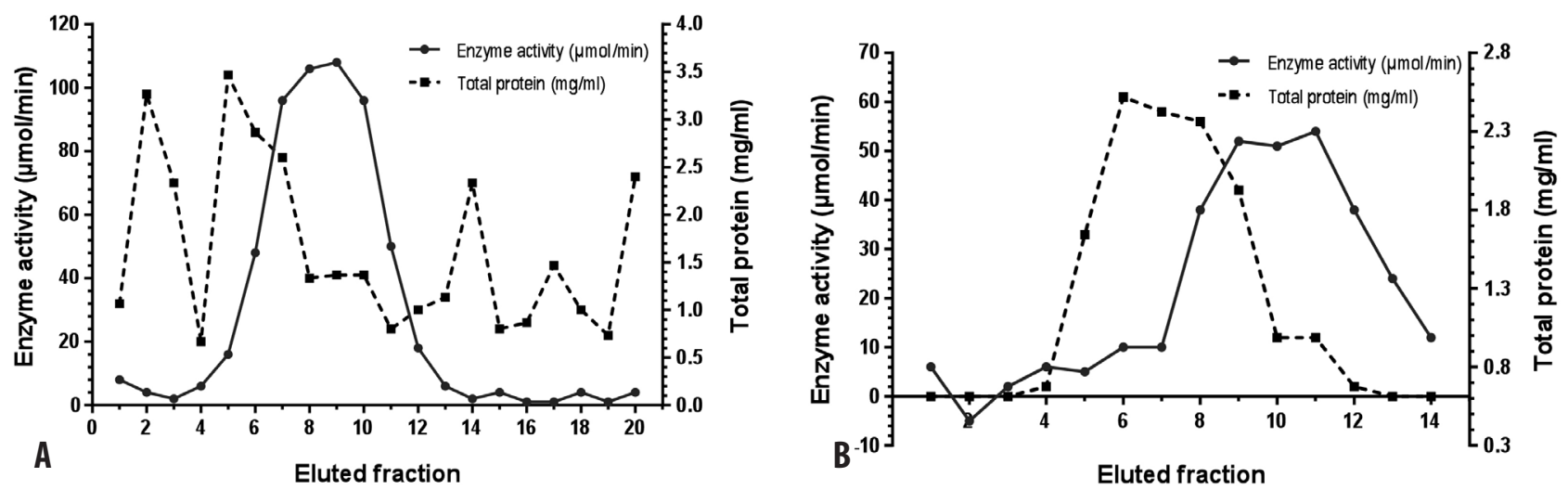

Fig. 1. Ion exchange (A) and gel chromatography (B) elution profiles of Eichhornia crassipes leaf peroxidase.

amounts of enzyme source were withdrawn at intervals of $10 \mathrm{~min}$. The withdrawn samples were then cooled on an ice bath for a period of $30 \mathrm{~min}$ and incubated at $25{ }^{\circ} \mathrm{C}$ for another $15 \mathrm{~min}$. The residual peroxidase activity (A) was then determined. The rate constant of inactivation (k) was obtained from the slope of a plot of the natural $\log$ of the residual activity (ln $\mathrm{A} / \mathrm{A}_{\mathrm{o}}$ ) versus time $(\mathrm{T})$ of heat exposure. The energy of inactivation of the enzyme was calculated from the slope of a straight line obtained using an Arrhenius plot of the natural logarithm of the first order rate constant for inactivation constant $(\mathrm{k})$ versus the reciprocal of absolute temperature $(\mathrm{K})$ (Thongsook, Barrett 2005).

\section{Thermal recovery profile of peroxidase}

The time-dependent thermal recovery profile of E. crassipes leaf peroxidase was determined by assaying peroxidase activity under different conditions. The enzyme source was heated in a water bath for 10,40 and $60 \mathrm{~min}$ at $75^{\circ} \mathrm{C}$. At each time interval, samples of the enzyme were withdrawn, allowed to cool at $25^{\circ} \mathrm{C}$ for periods of $20,30,40$ and $50 \mathrm{~min}$. Residual peroxidase activity was determined in the samples. The $\mathrm{Ca}^{2+}$-induced spontaneous recovery was studied and compared with recovery in the absence of $\mathrm{Ca}^{2+}$. Enzyme samples were heated in water bath for $1 \mathrm{~h}$ at $75{ }^{\circ} \mathrm{C}$. Then the enzyme was incubated with $0.005 \mathrm{M} \mathrm{Ca}^{2+}$ in phosphate buffer at $25^{\circ} \mathrm{C}$ for $5,15,30$ and $60 \mathrm{~min}$. The residual activity of the enzyme was then determined and expressed as a percentage, and compared with activity obtained in the absence of $\mathrm{Ca}^{2+}$.

\section{Substrate affinity of peroxidase and inhibition by $\mathrm{Hg}^{2+}$, EDTA and $\mathrm{Pb}^{2+}$}

Substrate affinity of E. crassipes leaf peroxidase for ABTS, pyrogallol, guaiacol and ascorbic acid was determined. E. crassipes leaf peroxidase activity at various concentrations of the substrates and the double reciprocal plots were used to estimate $\mathrm{K}_{\mathrm{M}}$ values for each of the substrates. The inhibition patterns of $\mathrm{Hg}^{2+}, \mathrm{Pb}^{2+}$ and EDTA on E. crassipes leaf peroxidase catalysis were evaluated. Double reciprocal plots of both inhibited and non-inhibited enzyme catalysis were obtained.

\section{Effect of urea on peroxidase}

A E. crassipes leaf peroxidase sample was incubated with 8 $\mathrm{M}$ urea solution. The period of incubation spanned $60 \mathrm{~min}$ at intervals of $10 \mathrm{~min}$. At each time the residual activity of peroxidase was determined.

\section{Results}

\section{Isolation and purification of $\mathrm{E}$. crassipes leaf peroxidase}

E. crassipes is an aquatic weed with invasive growth and in some countries it has raised environmental concerns because of the absence of natural predators. Several attempts have been made to control the spread of these plants in many parts of the world (Ghosheh 2005; Tellez et al. 2008). This study represents an attempt to convert these wastes to potential wealth by identifying and isolating an important commercial enzyme from E. crassipes leaves. Peroxidase was purified by the combination of ammonium sulphate precipitation and column chromatography on DEAE anion

Table 1. Summary of the purification steps of Eichhornia crassipes leaf peroxidase

\begin{tabular}{|c|c|c|c|c|c|}
\hline Purification step & $\begin{array}{c}\text { Enzyme activity } \\
\left(\mu \mathrm{mol} \mathrm{min}^{-1}\right)\end{array}$ & $\begin{array}{l}\text { Total protein } \\
\left(\mathbf{m g} \mathbf{m L}^{-1}\right)\end{array}$ & $\begin{array}{l}\text { Specific enzyme activity } \\
\qquad\left(\mu \mathrm{mol} \mathrm{min}^{-1} \mathrm{mg}^{-1}\right)\end{array}$ & $\begin{array}{l}\text { Purification } \\
\text { (fold) }\end{array}$ & Yield (\%) \\
\hline Crude enzyme extract & 507.52 & 25.44 & 19.94 & 1.00 & 100.0 \\
\hline$\left(\mathrm{NH}_{4}\right)_{2} \mathrm{SO}_{4}$ precipitation & 384.06 & 5.21 & 73.77 & 3.67 & 75.67 \\
\hline Ion exchange chromatography & 130.10 & 1.43 & 91.07 & 4.57 & 25.63 \\
\hline Gel filtration & 94.30 & 0.20 & 470.32 & 23.58 & 18.58 \\
\hline
\end{tabular}


exchange resin and Sephadex G-75 (Fig. 1, Table 1). DEAE chromatography (Fig. 1A) showed that fraction 9 exhibited the highest specific activity using guaiacol as substrate, with purification 4.57 fold. For Sephadex G-75 chromatography (Fig. 1B), fraction 6 showed the highest specific activity using guaiacol as a substrate, with purification 23.58 fold. The fractions were pooled together for characterization.

\section{Optimum $\mathrm{pH}$ of E. crassipes leaf peroxidase using different substrates}

Fig. 2 shows the effect of $\mathrm{pH}$ on E. crassipes leaf peroxidase activity using guaiacol, pyrogallol and ABTS as reducing substrate. The optimum $\mathrm{pH}$ for peroxidase for guaiacol was 8.9 , with steep decline at higher $\mathrm{pH}$. Using pyrogallol as a reducing substrate, the $\mathrm{pH}$ optimum for peroxidase was 5.5. There was much lower enzyme activity in the acidic range compared to basic values. E. crassipes leaf peroxidase activity had optimum $\mathrm{pH} 4.0$ using ABTS, with a sharp decrease in the basic range.

\section{pH stability of E. crassipes leaf peroxidase}

Fig. 3 shows the effect of $\mathrm{pH}$ on the stability of E. crassipes leaf peroxidase after $24 \mathrm{~h}$ exposure. The profile characteristics

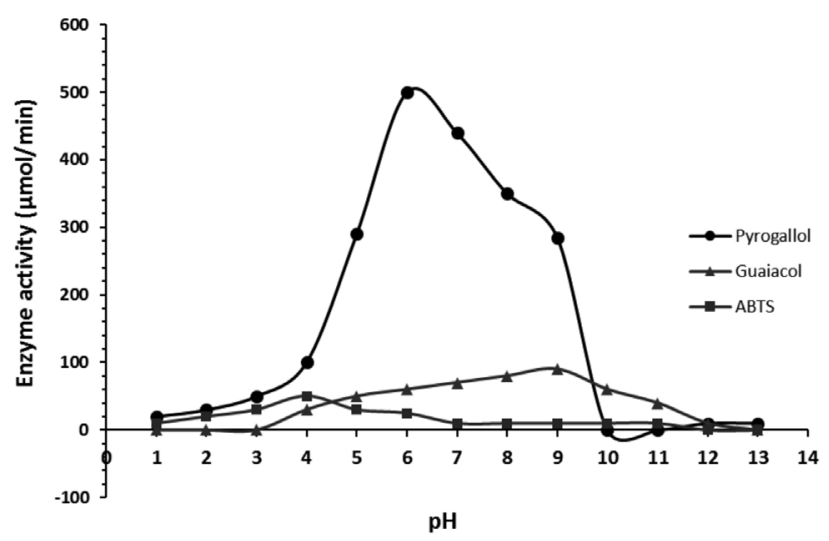

Fig. 2. Optimum $\mathrm{pH}$ of Eichhornia crassipes leaf peroxidase using guaiacol, pyrogallol and ABTS as substrates.

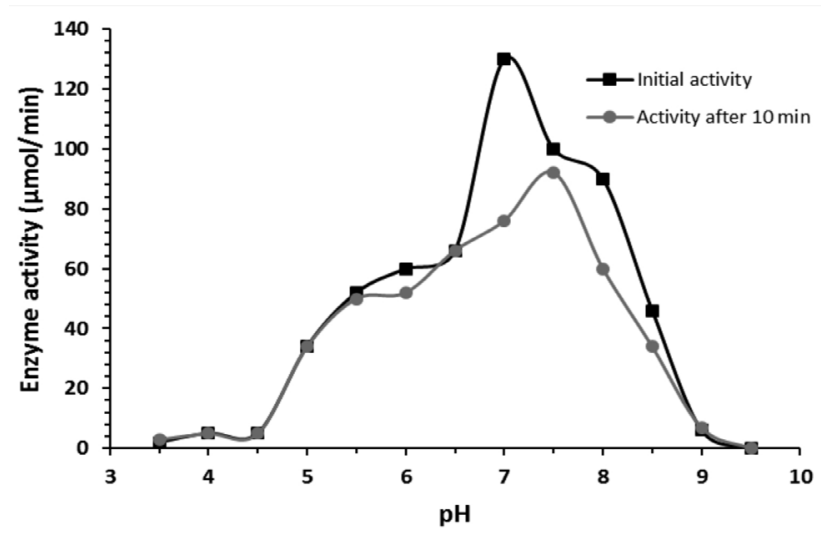

Fig. 3. $\mathrm{pH}$ stability of Eichhornia crassipes leaf peroxidase using guaiacol as substrate. obtained for the enzyme are similar, with a peak in enzyme activity at $\mathrm{pH}$ 7.0. This indicates that neutral $\mathrm{pH}$ is optimum for peroxidase activity during prolonged exposure.

\section{Optimum temperature and thermal stability of E. crassipes leaf peroxidase}

Fig. 4 shows effect of temperature on E. crassipes leaf peroxidase activity. The activity was in optimum at temperature $40{ }^{\circ} \mathrm{C}$ with a wide optimum temperature range, with a $60 \%$ residual enzyme activity maintained in approximately $70 \%$ of the temperature range.

The rate constant of inactivation $(\mathrm{k})$ was obtained from the slope of a plot of the natural log of the residual activity (ln A/A $)$ versus time (T) of heat exposure (Fig. 5A). The energy of inactivation of the enzyme was calculated from the slope of the straight line obtained using an Arrhenius plot of natural logarithm of the first order rate constant for inactivation constant $(\mathrm{k})$ versus the reciprocal of absolute temperature (K). In this study, the value of activation energy of heat inactivation $\left(E_{a}\right)$ for $E$. crassipes leaf peroxidase as obtained from Fig. 5B was $122 \mathrm{~kJ} \mathrm{~mol}^{-1}$.

\section{Thermal recovery profile of $\mathrm{E}$. crassipes leaf peroxidase}

Fig. 6 shows the time-dependent recovery profile of $E$. crassipes leaf peroxidase after thermal treatment at $75{ }^{\circ} \mathrm{C}$ for various duration. Recovery for the three treatments occurred at a fixed constant rate. Only slight recovery of enzyme activity was observed for the treatments. The thermal stability profile showed that loss of peroxidase activity at a particular temperature was time-dependent, while recovery increased during the first $20 \mathrm{~min}$, after which recovery became insignificant.

Fig. 7 shows the profile of E. crassipes leaf peroxidase when the temperature-denatured enzyme was allowed to spontaneously refold, compared to folding in the presence of $\mathrm{Ca}^{2+}$ in reaction mixture. The results showed that $\mathrm{Ca}^{2+}$ improved enzyme activity. Presence of $\mathrm{Ca}^{2+}$ resulted in two times higher peroxidase activity. The presence of $\mathrm{Ca}^{2+}$ also affected the reactivation of the denatured enzyme in a time-dependent manner.

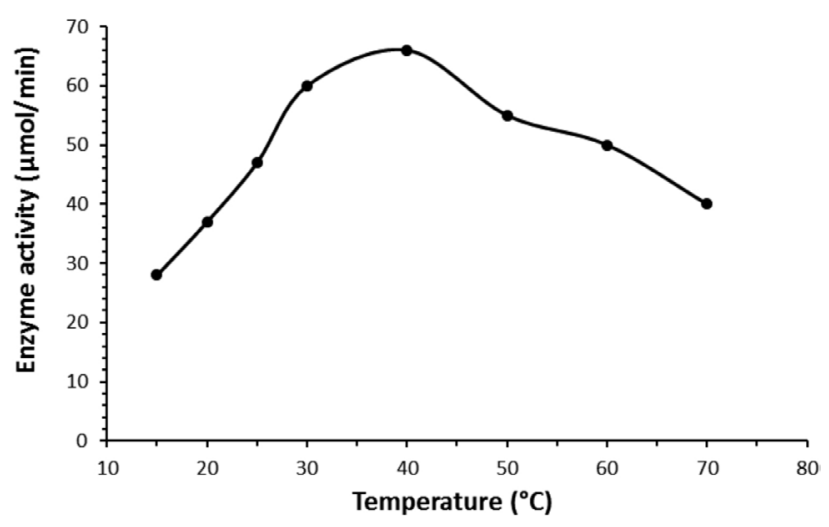

Fig. 4. Optimum temperature of Eichhornia crassipes leaf peroxidase. 

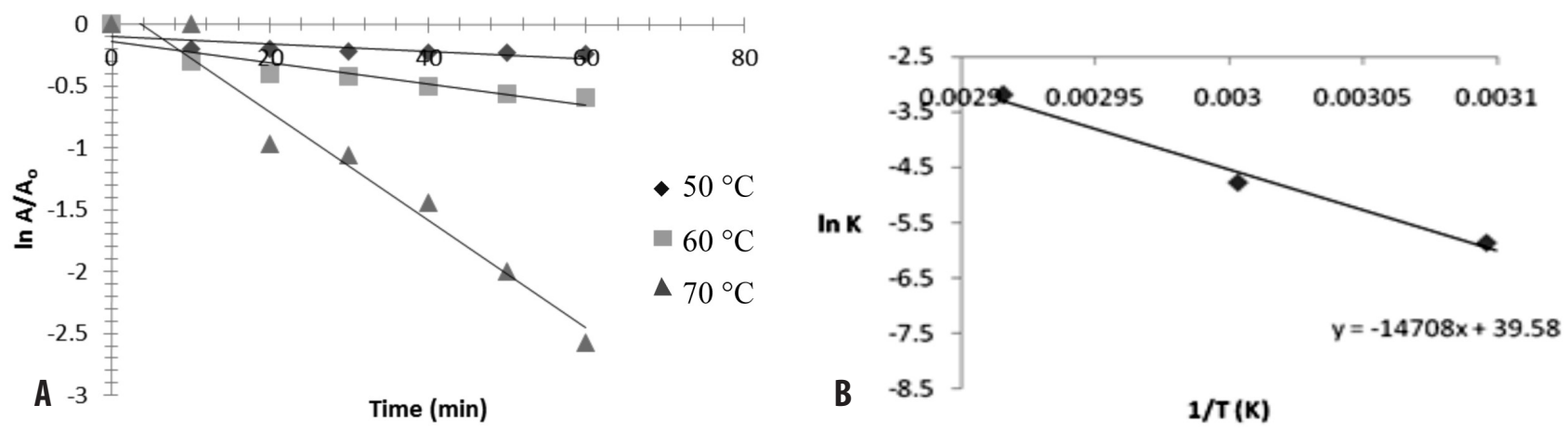

Fig. 5. (A) Rate of heat inactivation of Eichhornia crassipes leaf peroxidase. The ordinate represents the natural log of relative activity, the ratio of the activity $(A)$ to the original activity $\left(A_{o}\right)$ before heat treatment. (B) Arrhenius plot showing the effect of temperature on the rate constant for the thermal inactivation of peroxidase.

\section{Substrate specificity of $\mathrm{E}$. crassipes leaf peroxidase}

$\mathrm{K}_{\mathrm{M}}$ and $\mathrm{V}_{\max }$ values obtained for each of the three reducing substrates are given in Table 2. ABTS had the lowest $\mathrm{K}_{\mathrm{M}}$ value followed by pyrogallol. Despite its relatively high $\mathrm{K}_{\mathrm{M}}$ value, pyrogallol still gave the highest $\mathrm{V}_{\max }$ value followed by ABTS. E. crassipes peroxidase showed no activity using ascorbic acid as a substrate.

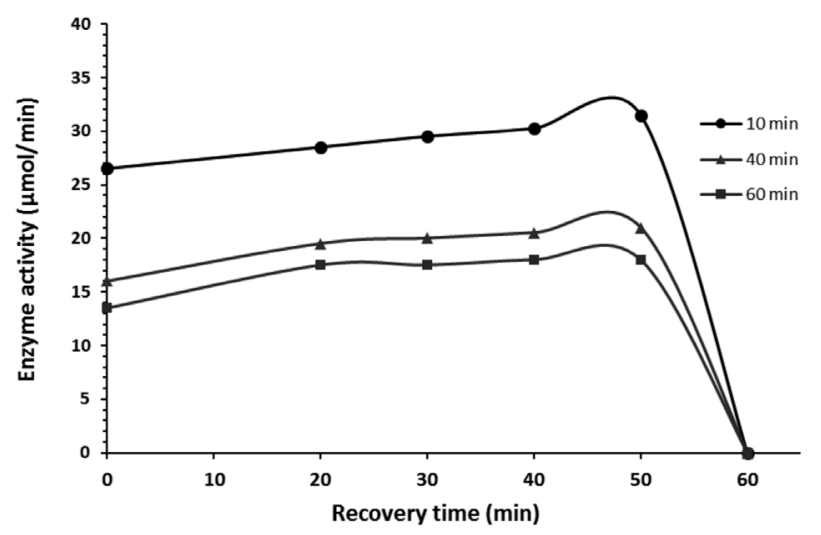

Fig. 6. Time-dependent spontaneous recovery of Eichhornia crassipes leaf peroxidase after thermal treatment for 10, 40 and 60 minutes at $75^{\circ} \mathrm{C}$.

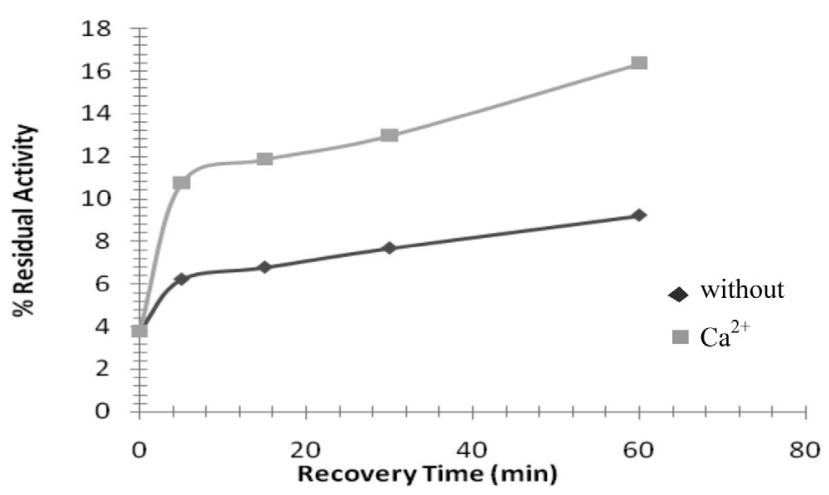

Fig. 7. $\mathrm{Ca}^{2+}$-induced recovery of Eichhornia crassipes leaf peroxidase after heating at $75^{\circ} \mathrm{C}$ for $1 \mathrm{~h}$.
Kinetics of inhibition of E. crassipes leaf peroxidase by $\mathrm{Pb}^{2+}$, $\mathrm{Hg}^{2+}$ and EDTA

Fig. $8 \mathrm{~A}, \mathrm{~B}$ and $\mathrm{C}$ show double reciprocal plots of the inhibitory effects of EDTA, $\mathrm{Pb}^{2+}$ and $\mathrm{Hg}^{2+}$ on activity of E. crassipes leaf peroxidase. For the two concentrations of $\mathrm{Hg}^{2+}$ studied, a mixed form of competitive inhibition was observed. The same pattern was also observed for EDTA and $\mathrm{Pb}^{2+}$ inhibition of the enzyme.

However, the effects of the studied inhibitors on the kinetic parameters of $E$. crassipes leaf peroxidase differed (Table 3).

\section{Effect of urea}

Urea is a common compound with ability to denature proteins. It acts by interfering with protein folding into its native conformation. E. crassipes leaf peroxidase maintained its stability under urea treatment, with about $70 \%$ of its activity in the presence of urea over a time range of $60 \mathrm{~min}$.

\section{Discussion}

The degree of purity (23.58 fold) of peroxidase attained in this study was higher than that (14.08 fold) obtained by Rehman et al. (1999). The specific activity $(470 \mu \mathrm{mol}$ $\mathrm{min}^{-1} \mathrm{mg}^{-1}$ ) of E. crassipes leaf peroxidase achieved after the last step of the three-step purification in this study was considerably higher than levels obtained previously for different sources of the enzyme: 15.21 units $\mathrm{mg}^{-1}$ (Rehman et al. 1999), 86 units $\mathrm{mg}^{-1}$ (Regalado et al. 1996), 135.44 units $\mathrm{mg}^{-1}$ (Maciel et al. 2007), 346.43 units $\mathrm{mg}^{-1}$ (Khatun et al. 2012) and 349.8 units $\mathrm{mg}^{-1}$ (Srinivas et al. 1999).

Table 2. Kinetic parameters of Eichhornia crassipes leaf peroxidase for different substrates

\begin{tabular}{|c|c|c|}
\hline Substrate & $\mathrm{K}_{\mathrm{M}}(\mathbf{m M})$ & 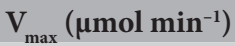 \\
\hline Guaiacol & 31.11 & 47.62 \\
\hline Pyrogallol & 21.91 & 755.36 \\
\hline ABTS & 6.45 & 161.29 \\
\hline
\end{tabular}

Ascorbic acid 

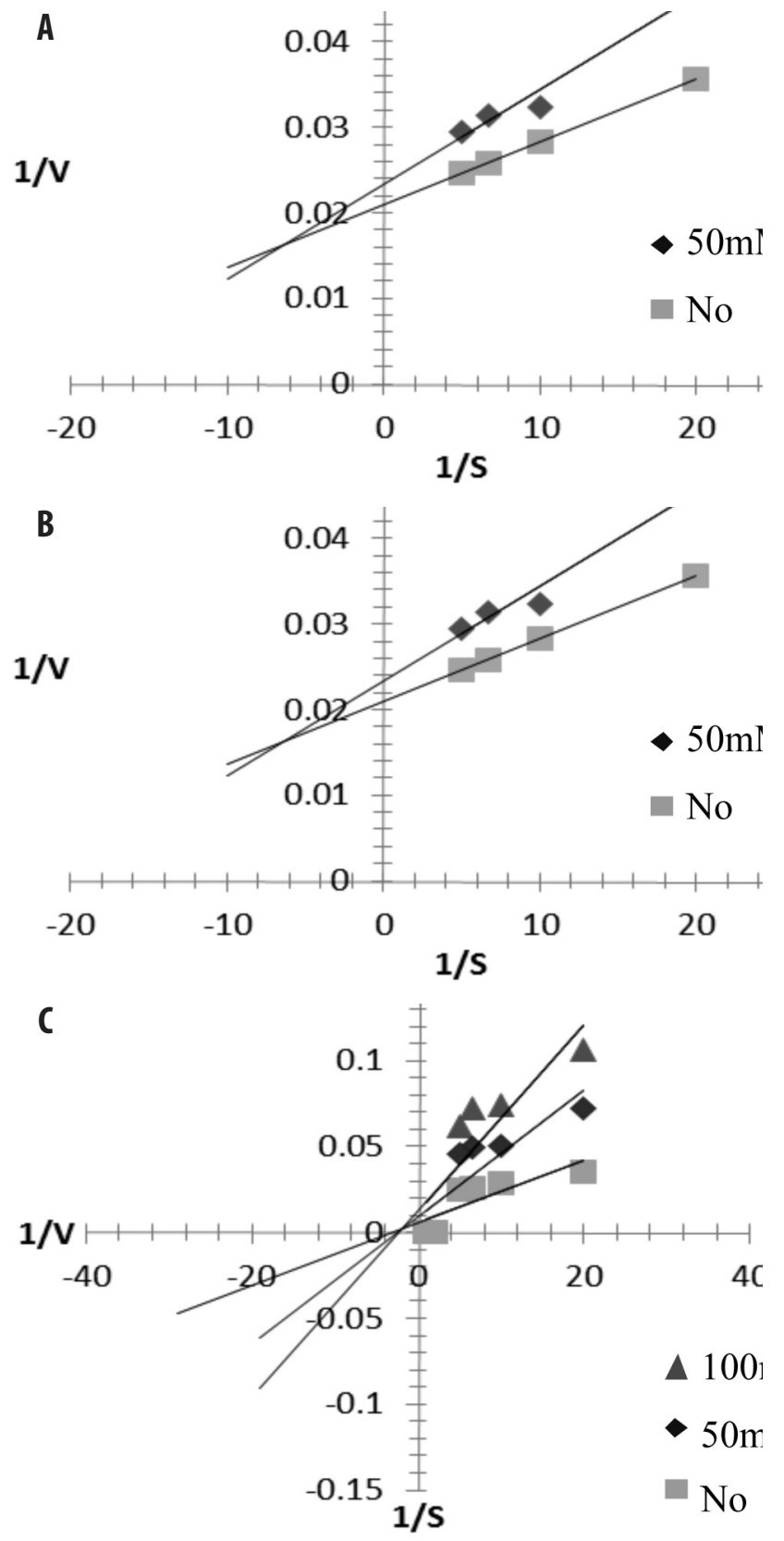

Fig. 8. Inhibition of Eichhornia crassipes leaf peroxidase by (A) EDTA, (B) $\mathrm{Pb}^{2+}$ and (C) $\mathrm{Hg}^{2+}$.

Peroxidases from different sources have been reported to have $\mathrm{pH}$ optima mostly in the range of 4.5 to 6.5 (Thongsook, Barrett 2005). The E. crassipes leaf peroxidase $\mathrm{pH}$ optima for pyrogallol and guaiacol are similar, with overlapping range. The range for $\mathrm{pH}$ optimum (5.2 to 6.8) using pyrogallol as a substrate was similar to that obtained by Gray and Montgomery (2003). However, peroxidases from some sources show higher $\mathrm{pH}$ optimum (Dubey et al. 2007). The differences in optimum $\mathrm{pH}$ for ABTS compared to the other two substrates may be a result of change in the ionization of substrates. This pattern was similar to those obtained for some previous studies (Melo et al. 1995; Gray,
Table 3. $\mathrm{K}_{\mathrm{M}}$ values of Eichhornia crassipes leaf peroxidase with selected inhibitors

$\begin{array}{lc}\text { Inhibitor } & \mathbf{K}_{\mathrm{M}}(\mathbf{m M}) \\ \text { None } & 31.11 \\ \mathrm{~Pb}^{2+} & 47.21 \\ \mathrm{EDTA} & 74.56 \\ \mathrm{Hg}^{2+}(50 \mathrm{mM}) & 50.56 \\ \mathrm{Hg}^{2+}(100 \mathrm{mM}) & 56.68\end{array}$

Montgomery 2003).

E. crassipes leaf peroxidase activity was high at acidic, alkaline, as well as neutral $\mathrm{pH}$, depending on the substrate type. In addition, the wide $\mathrm{pH}$ stability showed that the enzyme displayed an uncommonly high level of stability, which may favourably enhance its suitability for diverse industrial processes. The enzyme activity obtained over the range of temperature shows that $E$. crassipes leaf peroxidase has a rather large optimum temperature range, with $60 \%$ residual enzyme activity maintained within approximately $70 \%$ of the temperature range. Other studies have shown peroxidase activity to have a similar optimum temperature range. Bhatti et al. (2006) showed that activity of peroxidase from lettuce stem had an optimum temperature of $45^{\circ} \mathrm{C}$, while activity of peroxidase from cauliflower had optimum temperature of $30^{\circ} \mathrm{C}$ (Koksal, Gulcin 2008).

The activation energy of heat inactivation $\left(E_{a}\right)$ value $\left(122 \mathrm{~kJ} \mathrm{~mol}^{-1}\right)$ for E. crassipes leaf peroxidase obtained in this study is comparable to that of neutral broccoli isoperoxidase $\left(189 \mathrm{~kJ} \mathrm{~mol}^{-1}\right)$ reported by Thongsook and Barrett (2005), horesradish peroxidase (114k kJ mol-1; $\mathrm{Lu}$, Whitaker 1974), asparagus (140 kJ mol-1; Ganthavorn et al. 1991), and cauliflower (193 kJ mol ${ }^{-1}$; Lee, Pennesi 1984). Thonsook and Barett (2005) argued that higher purity can negatively affect the stability of a purified enzyme and thus resulting in a lower $E_{a}$ value. However, the stability can also be affected by the isoenzyme isolated. Other studies have shown that time range of thermal exposure can result in

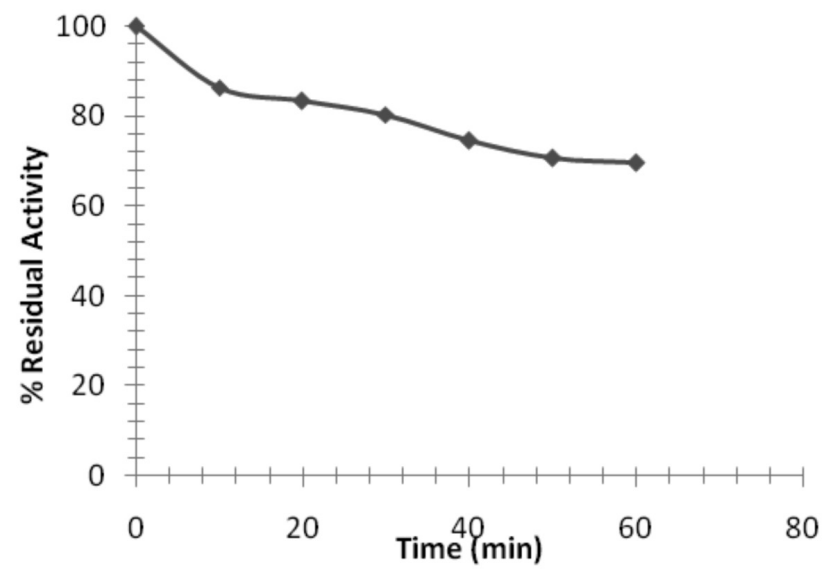

Fig. 9. Time-dependent effect of urea on the activity of Eichhornia crassipes leaf peroxidase. 
conflicting values (Duarte-Vazquez et al. 2003; Thongsook, Barrett 2005; Manu, Rao 2009; Nouren et al. 2013). A shorter time exposure has lower denaturing effect but higher $E_{a}$.

Thongsook and Barrett (2005) reported that broccoli peroxidase showed some ability to recover after heat treatment in a way that was time- and tempetraturedependent. However, since this study only considered treatment at $75{ }^{\circ} \mathrm{C}$, it is assumed that the reactivation of peroxidase was strictly time-dependent (especially in the first $20 \mathrm{~min}$ ). Studies have shown the ability of different peroxidases to recover after heat treatment (Halpin et al. 1989). Information on the reactivation of HRP after heat treatment are however conflicting (Thongsook, Barrett 2005).

Calcium is important for both activity and maintenance of the protein structure around the heme pocket (Barber et al. 1995; Thongsook, Barrett 2005). It has been reported that broccoli peroxidase has the ability to recover in the presence of $\mathrm{Ca}^{2+}$ after heat treatment (Thongsook, Barrett 2005). Gray and Montgomery (2003) reported a similar effect in corn steep water peroxidase, although greater recovery was observed. This study however, showed that a longer period of time was needed for $\mathrm{Ca}^{2+}$-induced recovery of E. crassipes leaf peroxidase. Possibly $\mathrm{pH}$ might have caused the low rate recorded.

The low $\mathrm{K}_{\mathrm{M}}$ value obtained for ABTS shows that $E$. crassipes leaf peroxidase had highest affinity for ABTS over both pyrogallol and guaiacol. The values obtained for pyrogallol oxidation by $E$. crassipes leaf peroxidase are however debatable. This is because autooxidation of pyrogallol was observed under the selected assay conditions even in the absence of $E$. crassipes leaf peroxidase. Absence of peroxidatic activity in the presence of ascorbic acid as a reducing substrate by peroxidase from different sources has been reported (Khatun et al. 2012).

Adsorption of specific heavy metals by some biomolecules results in structural and functional changes (Einollahi et al. 2006). Various studies have shown that peroxidase activity is susceptible to modulation by certain metal ions (Marzouki et al. 2005; Bhatti et al. 2006). The mixed type inhibition pattern obtained for each of the inhibitors indicates that they are able to inhibit E. crassipes leaf peroxidase by binding to either the free enzyme or its enzyme-substrate complex. The inhibition profile of E. crassipes leaf peroxidase by $\mathrm{Hg}^{2+}$ agrees with results obtained by Einollahi et al. (2006) on inhibitory effect of $\mathrm{Hg}^{2+}$ on horeseradish peroxidase. Other studies have shown that $\mathrm{Pb}^{2+}$ and EDTA have inhibitory effects on peroxidase from different sources (Hu et al. 2012; Khatunet al. 2012). The inhibitory effect of EDTA on E. crassipes leaf peroxidase was probably due to the sequestering effect of EDTA on $\mathrm{Fe}^{3+}$ and $\mathrm{Ca}^{2+}$, which are necessary for structural and functional integrity of the enzyme.

Time-dependent effect of urea showed that $E$. crassipes leaf peroxidase maintained its stability (70\% optimum activity). Nouren et al. (2013) showed that Citrus reticulata peroxidase retained $84.22 \%$ of its activity after $60 \mathrm{~min}$ incubation with urea. Thus, E. crassipes leaf peroxidase has moderate stability against chemical destabilization of urea. This characteristic increases its potential use in certain applications, where conformational stability of the enzyme is of great value.

In conclusion, peroxidases are becoming more useful in clinical, environmental and industrial applications, but these enzymes require stability over a broad range of physical and chemical conditions. E. crassipes leaves are available in large quantities in water bodies in Nigeria. The partially purified E. crassipes leaf peroxidase showed moderate stability under some of these conditions. Thus, E. crassipes leaf peroxidase may have great potential for industrial applications.

\section{References}

Adam W., Lazarus C.R., Saha-Moler C.R., Weichold O., Hoch U., Scherier P. 1999. Biotransformations with peroxidase. Adv. Biochem. Eng. 63: 74.

Barber K.R., Maranon M.J.R., Shaw, G.S., Van Huystee R.B. 1995. Structural influence of calcium on the heme cavity of cationic peanut peroxidase as determined by H-1-NMR spectroscopy. Eur. J. Biochem. 232: 825-833.

Bhatti H.N., Najma A., Asgher M., Hanif M.A., Zia M. 2006. Purification and thermal characterization of a novel peroxidase from a local chick pea cultivar. Prot. Pept. Lett. 13: 799-804.

Carlos R., Blanca E., Garcia A., Miguel A., Duarte V. 2004. Biotechnological applications of peroxidases. Phytochem. Rev. 3: 243-256.

Dawson R.M., Elliott D.C., Elliott W.H., Jones K.M. 1986. Data for Biochemical Research. $3^{\text {rd }}$ Ed. Oxford University Press, New York.

Deepa S., Arumughan C. 2002. Purification and characterization of soluble peroxidase from oil palm (Elaeis guinensis Jacq) leaf. Phytochemistry 61: 503-511.

Duarte-Vazquez M.A., Whitaker J.R., Rojo-Dominguez A., GarciaAlmendarez B.E., Regalado C. 2003. Isolation and thermal characterization of an acidic isoperoxidase from turnip roots. J. Agric. Food Chem. 51: 5096-5102.

Dubey A., Diwarkar S.K., Rawat S.K., Kumar P. 2007. Characterisation of ionically bound peroxidases from apple (Mallus pumilus) fruits. Prep. Biochem. Biotechnol. 37: 47-58.

Einollahi N., Abbasi S., Dashti N., Vaezzadeh F. 2006. Effect of mercuric chloride on kinetic properties of horseradish peroxidase. Iranian J. Public Health 35: 49-56.

Fabricio J.P, De Castro E.M., De Oliveira C., Pires M.F., Pereira M.P., Ramos S.J. 2004. Lead tolerance of water hyacinth (Eichhornia crassipes Mart. - Pontederiaceae) as defined by anatomical and physiological traits. Biol. Sci. 86: 3.

Fatima A., Husain Q. 2008. Purification and characterization of a novel peroxidase from bitter gourd (Momordica charantia). Prot. Pept. Lett. 15: 377-384.

Galati G., O'Brien P.J. 2004. Potential toxicity of flavonoids and other dietary phenolics: significance for their chemopreventive and anticancer properties. Free Radic. Biol. Medic. 37: 287-303. 
Ganthavorn C., Nagel C.W., Powers J.R. 1991. Thermal inactivation of asparagus lipoxygenase and peroxidase. J. Food Sci. 56: 4749.

Ghosheh H. Z. 2005. Constraints in implementing biological weed control: A review. Weed Biol. Manage. 5: 83-92.

Gray J.S., Montgomery R. 2003. Purification and characterisation of a peroxidase from corn steep water. J. Agric. Food Chem. 51: 1592-1601.

Halpin B. Pressey R., Jen J., Mondy N. 1989. Purification and characterization of peroxidase isoenzymes from green peas (Pisum sativum). J. Food Sci. 54: 644-649.

Hamid M., Khalil-ur-Rehman 2009. Potential applications of peroxidases. Food Chem. 115: 1177-1186.

Hu Y., Wu J., Luo P., Mo Y. 2012. Purification and partial characterization of peroxidase from lettuce stems. African J. Biotechnol. 11: 2752-2756.

Ito H., Hraoka N., Ohbayashi A., Ohashi Y. 1991. Purification and characterisation of rice peroxidases. Agric. Biol. Chem. 55: 2445-2454.

Khatun S., Ashraduzzaman M., Karim M.R., Pervin F., Absar N., Rosma A. 2012. Purificationa and characterization of peroxidase from Moringa oleifera L. leaves. Bioresources 7: 3237-3251.

Köksal E., Gulcin I. 2008. Purification and characterization of peroxidase from cauliflower (Brassica oleracea L. var. botrytis) buds. Prot. Peptide Lett. 15: 320-326.

Kvaratskhelia M., Winkel C., Thorneley R.N. 1997. Purification and characterization of a novel class III peroxidase isoenzyme from tea leaves. Plant Physiol. 114: 1237-1245.

Lee C.Y., Pennesi A.P. 1984. Isolation and further characterization of a heat-resistant peroxidase isoenzyme from cauliflower. $J$. Food Sci. 49: 1616-1617.

Lowry O.H., Rosebrough N.J., Fair A.L., Randal R.J. 1951. Protein measurement with the Folin-Ciocalteu's reagent. J. Biol. Chem. Soc. 193: 265-275.

Lu A.T., Whitaker J.R. 1974. Some factors affecting rates of heat inactivation and reactivation of horseradish peroxidase. $J$. Food Sci. 39: 1173-1178.

Maciel H.P.F, Gouvea C.M.C.P., Toyama M. Smolka M., Marangoni S., Pastore G.M. 2007. Extraction, purification and biochemical characterization of a peroxidase from Copaifera langsdorffii leaves. Quim. Nova 30: 1067-1071.

Manu B.T., Rao U.J.S.P. 2009. Calcium modulated activity enhancement and thermal stability study of a cationic peroxidase purified from wheat bran. Food Chem. 114: 66-71.

Marzouki S.M., Limam F., Smaali M.I., Ulber R., Marzouki M.N.
2005. A new thermostable peroxidase from garlic Allium sativum: purification, biochemical properties, immobilization, and use in $\mathrm{H}_{2} \mathrm{O}_{2}$ detection in milk. Appl. Biochem. Biotechnol. 127: 201-214.

Melo N.S., Cabral J. M.S., Fevereiro M.P. 1995. Extracellular peroxidases from cell suspension cultures of Vaccinium myrtillus. Purification and characterization of two cationic enzymes. Plant Sci. 106: 177-184.

Nouren S., Bhatti H.N., Bhatti I.A., Asgher M. 2013.Kinetic and thermal characterization of peroxidase from peels of Citrus reticulata var. Kinnow. J. Anim. Plant Sci. 23: 430-435.

Passardi F., Cosio C., Penel C., Dunand C. 2005. Peroxidases have more functions than a Swiss army knife. Plant Cell Rep. 24: 255-265.

Regalado C., García-Almendárez B.E., Duarte-Vázquez M.A. 2004. Biotechnological applications of peroxidases. Phytochem. Rev. 3: 243-256.

Regalado C., Rodrogo M., Alvarruiz A., Frigola A. 1996. Thermal inactivation at high temperatures and regeneration of green asparagus peroxidase. J. Food Prot. 59: 1065-1071.

Rehman K.U., Yaqub M., Sheikh M.A., Arshad M. 1999. Extraction and evaluation of peroxidases from various vegetable sources. Int. J. Agric. Biol. 1: 170-173.

Rudrappa T., Lakshmanan V., Kaunain R., Singara N.M., Neelwarne B. 2007. Purification and characterization of an intracellular peroxidase from genetically transformed roots of red beet (Beta vulgaris L.). Food Chem. 105: 1312-1320.

Srinivas N.D., Rashmi K.R., Raghavarao K.S.M.S. 1999. Extraction and purification of a plant peroxidase by aqueous two phase extraction coupled with gel filtration. Process Biochem. 35: 43-48.

Tellez T.R, Lopez E.M., Granado G.L., Perez E.A., Lopez R.M., Guzman J.M.S. 2008. The water hyacinth, Eichhornia crassipes: an invasive plant in the Guadiana River Basin (Spain). Aquatic Invasions 3: 42-53.

Thongsook T., Barrett M. 2005. Purification and partial characterisation of broccoli (Brassica oleracea var. italica) peroxidase. J. Agric. Food Chem. 53: 3206-3214.

Torres E., Bustos-Jaimes I., Le-Borgne S. 2003. Potential use of oxidative enzymes for the detoxification of organic pollutants. Appl. Catal. B Environ. 46: 1-15.

Veitch N.C. 2004. Horseradish peroxidase: a modern view of a classical enzyme. Phytochemistry 65: 249-259.

Yemenicioglu A., Ozkan M., Cemeroglu B. 1998. Partial purification and thermal characterisation of peroxidase from okra (Hibiscus esculentum). J. Agric. Food Chem. 46: 41-58. 